ЛЮБОМИРА ІЛІЙЧУК, кандидат педагогічних наук, доиент, кафедра педагогіки початкової освіти, ДВНЗ "Прикарпатський національний університет імені Василя Стефаника", Україна ORCID ID 0000-0003-4274-6903 liubomyra.iliichuk@gmail.com

\title{
ЕЛЕКТРОННИЙ ПІДРУЧНИК ЯК ІННОВАЦІЙНИЙ ЗАСІБ НАВЧАННЯ
}

\author{
LIUBOMYRA ILIICHUK, PhD in Education, Associate Professor, \\ Department of Pedagogy of Primary Education, Vasyl Stefanyk \\ Precarpathian National University, Ukraine
}

\section{E-TEXTBOOK AS AN INNOVATIVE MEANS OF EDUCATION}

У статті розкрито можливості використання е-підручника як сучасного засобу навчання здобувачів освіти в умовах закладів загальної середньої освіти. Здійснено аналіз і систематизовано різні підходи до трактування поняття електронний підручник. Узагальнено вимоги до сучасного епідручника та подано особливості його впровадження в освітній процес початкової школи. Наголошено, що використання електронних засобів навчального призначення набуло реалізації й утілення у зв'язку з реформою Нової української школи. Проаналізовано електронні підручники для початкової школи, які беруть участь у Всеукраїнському експерименті "Електронний підручник для загальної середньої освіти".

Ключові слова: електронний підручник, електронний засіб навчального призначення, електронний ресурс, електронне видання, засіб навчання, здобувач освіти.

The article discloses the possibility of using e-textbook as an innovative educational means at general secondary schools. Different approaches to the interpretation of the notion "etextbook" have been analyzed and systematically organized. The paper generalizes basic requirements for a modern e-textbook and describes how to provide them for primary school. A causal link between an e-textbook and educational reform New Ukrainian School has been outlined. According to the All-Ukrainian experimental project
"Electronic Textbook for General Secondary Education" the e-textbooks for primary school have also undergone a detailed analysis.

Key words: e-textbook, digital education tool, e-resource, epublication, learning tool, applicant.

Мета: з'ясувати сутність поняття електронний підручник, дослідити особливості його структури та обгрунтувати дидактичні вимоги до створення й упровадження е-підручників в освітній процес закладів загальної середньої освіти.

Постановка проблеми в загальному вигляді. Сьогодні система освіти України вступила в період швидких фундаментальних змін, які характеризуються якісно новим розумінням цілей і цінностей освіти, новими концептуальними підходами до використання сучасних технологій і засобів навчання. Глобалізація знань, стрімкі темпи накопичення та поширення інформації, що спостерігаються в останні десятиліття і викликані розвитком інформаційно-комунікаційних технологій, викликають появу нових підходів до організації навчального процесу в закладах освіти. Реалізація багатьох завдань, які стоять перед галуззю на даному етапі, неможлива без застосування сучасних засобів навчання, зокрема електронних підручників, які в найближчому майбутньому створять суттєву конкуренцію друкованим виданням. Значення електронних підручників зростає, виходячи з активного впровадження у навчальний процес 33СО інформаційних технологій, що суттєво впливає на результативність навчання здобувачів освіти і розширює можливості навчального процесу загалом.

У сучасних умовах електронний підручник дедалі частіше стає нормою освітньої діяльності, відтак це активізувало дослідницьку діяльність у напрямах вивчення сутності, особливостей, функцій та місця е-підручника в навчальному процесі, організаційних засад його створення, вимог до нього і критеріїв оцінювання. Однак сьогодні на рівні відповідних органів державного управління, а також серед фахівців ще не сформовано єдиних поглядів щодо принципів побудови, структури, форми подання інформації, дидактичних вимог до електронних підручників. Усе це визначає необхідність усебічного вивчення особливостей типологізації, розробки й упровадження е-підручників в освітній процес закладів загальної середньої освіти.

Аналіз досліджень і публікацій. Питання, пов'язані зі створенням та використанням електронних засобів навчання, зокрема електронних підручників, досліджують В. Анохін, Л. Білоусова, В. Волинський, Ю. Жук, Л. Зайнутдінова, І. Іваськів, Н. Клокар, В. Клочко, Н. Кононець, О. Кохан, О. Лемента, С. Лещук, О. Плоха. Проблемою типологізації електронних видань займаються А. Антохова, К. Бугайчук, С. Водолазька, О. Гриценчук, М. Женченко, Т. Киричок, Н. Кононець, Т. Купріянова, Е. Огар, Ю. Петяк, М. Стахів. Сутнісні характеристики електронних підручників, дидактичні аспекти їх упровадження в освітній процес розкривають Л. Білоусова, Н. Богданова, В. Вембер, Л. 
Гризун, Ю. Дорошенко, М. Жалдак, В. Лапінський, В. Мадзігон, Н. Морзе, Н. Тверезовська, Н. Фіголь. Узагальнення досвіду використання електронних засобів навчального призначення та визначення критеріїв оцінювання якості електронних підручників здійснюють В. Дем'яненко, І. Воротникова, О. Геращенко, А. Кирилов, Н. Сливіна, С. Фомін та інші.

Аналіз наукової літератури вказує на те, що існує багато публікацій присвячених питанням створення та використання електронних навчальних видань. Однак, незважаючи на те, що поняття електронний підручник функціонує в науковому обігу протягом останніх кількох десятиліть, сьогодні не визначено структури, принципів побудови та основних вимог до укладання е-підручника; відсутня й одностайність думок учених щодо визначення самого терміна електронний підручник, немає єдиної точки зору щодо його змістового наповнення. Так, деякі науковці стверджують, що електронний підручник є ресурсом, що містить систематизовані навчальні матеріали 3 певної галузі знань, створення, розповсюдження i використання якого можливе лише за допомогою сучасних інформаційних технологій. Інші дослідники займають протилежну позицію і застерігають, що формальний термінологічний перехід від друкованої навчальної книги до електронної не відтворює тих революційних перетворень, які пропонує прогрес у галузі інформаційних технологій. Отож діапазон думок щодо сутності поняття електронний підручник досить широкий $\mathrm{i}$ коливається від примітивного електронного аналога друкованого видання до складних систем на основі штучного інтелекту, що підтверджує відсутність стандартизації термінології щодо електронних навчальних видань в Україні (Кухарський, 2017, c. 85).

Виклад основного матеріалу дослідження. Стрімкий розвиток ринку електронних видань у нашій державі зумовлений освітніми потребами, зокрема реформою Нової української школи, яка передбачає обов'язкове створення таких різноманітних освітніх продуктів, як електронні навчальні видання. Використання гаджетів, удосконалення комп'ютерної графіки та анімації, доступ до нових інформаційних програм робить застосування е-підручників неймовірно цікавим та за правильного пропорц- ійного дозування досить корисним (Воробеиьь, 2019, с. 398). Усе це актуалізує потребу в дослідженнях цих медійних продуктів (Стахів, 2019). 3 огляду на недосконалість відповідної нормативно-технічної бази гостро постає проблема типологізації електронних видань. Варто зауважити, що ДСТУ 7157:2010. "Видання електронні. Основні види та вихідні відомості" (Видання..., 2010) сьогодні практично не відображає реального стану речей і є застарілим, адже цей сегмент медіа досить динамічно розвивається й удосконалюється. Натомість нова редакція ДСТУ 3017:2015. "Видання. Основні види. Терміни та визначення понять" оминає увагою такий термін, як електронний підручник (Видання..., 2015).

Слід відмітити, дещо поглиблює i розширює класифікацію нових освітніх продуктів упровадження реформи НУШ Положення про електронний підручник (Положення..., 2018) та Положення про електронні освітні ресурси (Положення..., 2012). Так, у Положенні про електронний підручник подано таке визначення даного поняття: "е-підручник - це електронне навчальне видання із систематизованим викладенням навчального матеріалу, що відповідає освітній програмі, містить цифрові об'єкти різних форматів та забезпечує інтерактивну взаємодію" (Положення..., 2018), а його складовими частинами є емпіричні, теоретичні, практичні та демонстраційні компоненти, засоби пошуку, відображення, перевірки знань тощо.

У теперішній час концептуальні засади електронного підручника, їх типологізація, розробка й упровадження перебувають на етапі становлення. Дослідниками проблеми пропонуються різноманітні варіанти визначення даного поняття та його основних ознак. Так, на переконання $\mathrm{H}$. Кононець, електронний підручник це універсальний інтерактивний, гіпермедійний, методичний і дидактичний підручник, який містить широке коло питань $з$ тем однієї дисципліни (або різних навчальних дисциплін), викладених у компактній формі гіпертекстового середовища, i призначений для використання у навчальному процесі (Кононець, 2009).

Науковець К. Бугайчук розглядає електронний підручник як навчальне електронне видання із системати- зованим викладом дисципліни (iї розділу, частини), у якому рівнозначно і взаємопов'язано за допомогою відповідних програмних засобів існує текстова, звукова, графічна та інша інформація, що забезпечує безперервність і повноту дидактичного циклу процесу навчання, служить для групового, індивідуального або індивідуалізованого навчання, відповідає навчальній програмі й призначене для використання у навчальному процесі (Бугайчук, 2011).

Електронний підручник, на думку В. Волинського, являє собою нормативно-автономний засіб навчання, створений на базі експериментального або чинного традиційного підручника, але 3 розширеними змістовими, операційно-діяльнісними, інформаційними можливостями унаочнення та пояснення явищ і процесів, керівництва навчальною діяльністю користувача у процесі самонавчання. Основне призначення електронного підручника полягає в активізації процесу навчання у процесі вивчення, повторення, узагальнення, систематизації знань, формування умінь $\mathrm{i}$ навичок, застосування їх у практичній діяльності (Волинський, 2007).

В. Мадзігон наводить такі тлумачення поняття електронний підручник, як: "програмно-інформаційна система, яка складається із програм для ЕОМ, що реалізують сценарії навчальної діяльності, і певним чином підготовлених знань (структурованої інформації і системи вправ для її осмислення й закріплення)"; "гіпертекстовий документ за формою подання і традиційний підручник за своїм змістом"; "електронний навчальний курс, який містить систематичний виклад навчальної дисципліни чи іiі розділу, відповідає державному стандарту і навчальній програмі й офіційно затверджений як даний вид видання" (Мадзігон, 2006).

Дослідник С. Раков зазначає, що для забезпечення ефективності навчання 3 використанням е-підручників вони повинні втілювати кращі сторони традиційних засобів і реалізовувати нові якості та функції, серед яких:

- гіпертекстовість - можливість перегляду навчального матеріалу за гіперпосиланнями (асоціативними зв'язками, змістом, індексним покажчиком);

- мультимедійність - здатність використання засобів мультимедіа (графіка, звук, анімація, відео тощо) для 
більш ефективного подання навчального матеріалу;

- інтегрованість - електронні посібники включають не лише навчальні матеріали, а й запитання, тести для самоконтролю та контролю, гіперпосилання на іншу навчальну і довідкову літературу;

- конструктивність - навчальні курси на основі інформаційно-комунікаційних технологій можуть бути побудовані за принципами конструктивізму в навчанні, згідно з якими навчання реалізується через конструювання когнітивних (уявних) моделей через експерименти з реальністю або іiї комп'ютерними моделями, які побудовані за допомогою фахових пакетів або спеціалізованих діяльнісних середовищ;

- інтерактивність - можливість забезпечення зворотного зв'язку, яка забезпечує керованість процесу навчання (Раков, 2005).

Загалом аналіз дослідження даної проблематики дає підстави стверджувати про неоднозначність трактування поняття електронний підручник. Відтак, виходячи із ключових о3нак, характеристик і функцій, покладених на підручник як засіб навчання, дослідники класифікують електронні підручники на такі типи:

• статичний (трансформація традиційного (паперового) підручника в електронному форматі, створений у форматі PDF, DJVU тощо, відповідає паперовому аналогу, забезпечує можливість друку в повному обсязі та розташування на навчальній платформі, але без доступу до окремих фрагментів);

- з елементами мультимедіа (створений у форматі HTML, HTM тощо, має елементи мультимедіа, відповідає паперовому аналогу, містить мультимедійні елементи (гіпертекст, гіперпосилання), лінійну навігацію керування, передбачає можливість друку окремих статичних фрагментів i розташування на навчальній платформі, але без доступу до окремих фрагментів);

• мультимедійний (комплекс логічно пов'язаних структурованих дидактичних одиниць, представлених у цифровому вигляді, забезпечує можливість розташування е-підручника на навчальній платформі, має покрокову навігацію керування, оснащення мультимедійними елементами (анімація, симуляція, звук тощо), забезпечує друк як окремих елементів підручника, так і в повному обсязі);
• інтерактивний (інтегрує в одному програмному продукті різноманітні види даних (текст, ілюстрації, анімація, таблиці, аудіо- та відеозображення, симуляція тощо), забезпечує можливість розташування на навчальній платформі, передбачає наявність покрокової навігації та блоку контролю й самоконтролю, реалізацію інтерактивних вправ, використання на різних пристроях, можливість розташування в соціальній мережі та друку окремих фрагментів е-підручника);

• інтелектуальний (комплекс загальнокористувацьких інструментів, за допомогою яких учитель може створити контент уроків, з можливістю підстановки, заміни чи трансформації навчального матеріалу) (Plebanska, 2012, c. 12);

- адаптивний (покликаний використовувати штучний інтелект та забезпечувати індивідуальну освітню траєкторію навчання кожному учню на основі аналізу його потреб і успішності, а вчитель у таких умовах є лише модератором для вибору контенту i мотивує до навчання) (Воротникова, 2019, c.27)

Як бачимо, електронне видання в рамках електронного навчального дискурсу являє собою складне соціокомунікативне явище, що складається $з$ учасників комунікації (комунікант 1 (автор), комунікант 2 (редактор), комунікант 3 (програміст), реципієнт), має два тексти - первинний та вторинний (електронний), що породжені екстралінгвістичними факторами (знання про світ, потреби, настанови і конкретні цілі комунікаторів) (Фіголь, 2012, с. 53). Педагогічна цінність електронних ресурсів закладається у процесі їх проєктування та розробки, коли мають бути враховані педагогічні, психологічні та методичні вимоги щодо створення якісних е-підручників, які відрізняються від вимог до друкованих видань.

В Україні питання інформатизації освіти, зокрема, використання електронних засобів у процесі навчання здобувачів освіти набуло реалізації та втілення у зв'язку із масштабною реформою Нової української школи. Відтак видається ряд наказів МОНУ і постанов КМУ щодо впровадження в освітній процес закладів освіти електронних підручників. Так, згідно 3 постановою КМУ Про порядок забезпечення підручниками та посібниками здобувачів повної загальної серед- ньої освіти і педагогічних працівників (Порядок..., 2019) учні та вчителі повинні бути забезпечені як паперовими, так і електронними підручниками, при чому е-підручниками вважаються самостійні електронні видання і підручники з аудіосупроводом, а не електронні версії друкованих видань. Відповідно до наказу МОН Про проведення експерименту всеукраїнського рівня за темою "Електронний підручник для загальної середньої освіти" (серпень 2018 року - серпень 2021 року) (Про проведення...., 2018) упровадження е-підручників повинно відбуватися поступово, адже досвіду користування подібними продуктами майже немає. Так, 3 2018/2019 н. р. і до сьогодні в експериментальних школах відбувається застосування е-підручників з інтегрованих курсів "Мистецтво" і "Я досліджую світ", "Математика", "Українська мова. Буквар".

На сайті Інституту модернізації змісту освіти (https://imzo.gov.ua) розміщено інформацію про видання, які беруть участь у конкурсі електронних підручників і яким надано гриф "Рекомендовано Міністерством освіти і науки України". Серед них: 3 е-підручники інтегрованого курсу "Мистецтво" для 1 класу 33СО, 3 епідручники інтегрованого курсу "Мистецтво" для 2 класу 33СО, 5 епідручників інтегрованого курсу "Я досліджую світ" для 1 класу 33СО, 2 е-підручники інтегрованого курсу"Я досліджую світ" для 2 класу 33СО, 3 е-підручники "Математика" для 1 класу 3ЗСО, 1 е-підручник "Українська мова. Буквар" для 1 класу $33 \mathrm{CO}$ (https://imzo.gov.ua/elektronnyjpidruchnyk/konkursnyy-vidbirproektiv-elektronnykh-pidruchnykiv$2019 /$ perelik-elektronnykhpidruchnykiv-iaki-berut-uchast-ukonkursnomu-vidbori-proiektivelektronnykh-pidruchnykiv-dliaeksperymental-nykh-zakladiv-zahalnoi-seredn-oi-osvity-u-2019-rotsi/). Зауважимо, що означені підручники створені на платформах "Розумники", "Bristar" та "MozaWeb".

За результатами проведеного нами аналізу електронних підручників, які беруть участь у Всеукраїнському експерименті "Електронний підручник для загальної середньої освіти", можемо стверджувати, що вони відповідають ключовим вимогам, які ставляться до видань даного типу (Ілійчук, 2019). Зокрема, інформація в е-підручниках логічно побу- 
дована, чітко структурована і систематизована, відповідає навчальним програмам дисциплін; підручники мають цілісний та інтуїтивно зрозумілий інтерфейс, інформують щодо теми, відкритої на екрані, містять інструкції до виконання вправ і завдань; уміщують ілюстративні, мультимедійні матеріали, інтерактивні елементи розміщено відповідно до логіки викладу навчального матеріалу, вони не перевантажують сприймання навчального матеріалу, їх використання вмотивоване і доцільно правильне, сприяє активізації пізнавальної діяльності здобувачів освіти; у виданнях наявні засоби навігації, покажчики, можливість виділяти текст і системи контролю знань. Утім не всі електронні підручники забезпечують можливість роботи з ними на трьох чи більше операційних системах, що є однією з вимог до таких видань; у деяких з них наявна лише звуковий супровід, без текстової інструкції; окремі видання не передбачають змоги відімкнення звукового супроводу всередині підручника.

Висновки та перспективи подальших досліджень. Сьогодні актуальність розробки і використання електронних підручників як інноваційного засобу навчання здобувачів освіти визначається стратегіями розвитку Нової української школи. Упровадження в освітній процес закладів загальної середньої освіти електронних ресурсів і електронних засобів навчального призначення дозволяє здійснити якісні зміни в системі навчання здобувачів освіти, відкриває широкі можливості для поглиблення теоретичної бази знань, посилення прикладної спрямованості навчання, підвищення рівня пізнавальної активності, розкриття творчого потенціалу вчителів і учнів відповідно до їх запитів, нахилів та здібностей.

Аналіз пропозицій українських видавництв щодо електронних засобів навчального призначення та епідручників показав, що даний ринок розвивається і користується попитом, але не всі вони готові до створення якісних сучасних електронних підручників. Державна політика щодо розбудови нової освітньої платформи для розміщення та експертизи електронних підручників, затвердження Положення про е-підручники, проведення Всеукраїнського експерименту"Електронний підручник для загальної середньої освіти" є дієвими чинниками впровадження е- підручників в освітній процес закладів загальної середньої освіти.

Перспективи подальших досліджень.

Розробка та впровадження епідручників в освітній процес сучасної школи перебувають у процесі динамічного розвитку, а дидактичний зміст даного поняття на сьогодні ще уточнюється і конкретизується, становлячи великий інтерес для педагогічних досліджень. Перспективними напрямами подальших наукових розробок у даному напрямі вважаємо висвітлення досвіду створення електронних підручників і їх застосування у навчальному процесі початкової школи, здійснення аналізу програмних засобів створення е-підручників для закладів освіти.

\section{СПИСОК ЛІТЕРАТУРИ}

Бугайчук, К. Л. (2011). Електронний підручник: поняття, структура, вимоги. Інформачійні технології $i$ засоби навчання, Вип. 22 (2). Doi 10.33407/itlt.v22i2.437

Видання електронні. (2010). Основні види та вихідні відомості. ДСТУ 7157:2010.

Видання. (2015). Основні види. Терміни та визначення. ДСТУ 3017:2015.

Волинський, В. П. (2007). Теоретичні основи створення електронних підручників. Проблеми сучасного підручника, 7, 28-30.

Воробець, О. (2019). Інформаційні технології у контексті формування цифрової компетентності майбутніх учителів. Електронне наукове фахове видання "Відкрите освітнє е-середовище сучасного університеmу". Спецвипуск "Нові педагогічні nідходи в STEAM освіті", 398-404. Doi 10.28925/2414-0325.2019s36.

Воротникова, І. (2019). Досвід використання е-підручників і електронних засобів навчального призначення в умовах цифровізації загальної середньої освіти України. Інформаційні технології $і$ засоби навчання, 71 (3), 23-39. Doi 10.33407/ Ittl.V71i3.2552.

Ілійчук, Л. (2019). Сучасні вимоги щодо розробки та впровадження електронних підручників в освітній процес початкової школи. Електронне наукове фахове видання "Відкрите освітнє е-середовище сучасного університету". Спецвипуск "Нові педагогічні підходи в STEAM ocвimi", 123-132. Doi 10.28925/2414- 0325.2019s11.

Кононець, Н. В. (2009). Аспекти педагогічної майстерності викладача: розробка електронних підручників. Витоки педагогічної майстерності, 6, 202-210.

Кухарський, В., Осередчук, О. (2017). Електронний підручник в українській вищій освіті: від ідеї створення до реалізації. Вісник Національного університету "Львівська політехніка", 879, 84-90.

Мадзігон, В. М. (2006). Теоретичні засади створення електронних підручників. Проблеми сучасного підручника: збірник наукових працьь Інституту педагогіки АПН Украї$н и, 6,34-38$.

Про затвердження Положення про електронний підручник. (2018). № 440 .

Про затвердження Положення про електронні освітні ресурси. (2012). № 1060.

Про затвердження Порядкузабезпечення підручниками та посібниками здобувачів повної загальної середньої освіти і педагогічних працівників. (2019). №41.

Про проведення експерименту всеукраїнського рівня за темою "Електронний підручник для загальної середньої освіти" (Е-book for secondary education (EBSE)), серпень 2018 року - серпень 2021 року. (2018). № 957 .

Раков, С. А. (2005). Формування математичних компетентностей учителя математики на основі дослідницького підходу в навчанні з використанням інформаційних технологій. (Дис. доктора пед. наук). Національний педагогічний університет імені М. П. Драгоманова, Харків.

Стахів, М. (2019). Е-підручники для української школи: проблеми підготовки. Записки Львівської національної наукової бібліотеки України імені В. Стефаника, 11(27), 169-180.

Фіголь, Н. (2012). Електронний навчальний посібник чи підручник: до проблеми визначення. Вісник $\mathrm{Ha}$ ціонального університету "Львівська політехніка": Серія "Проблеми української термінологї̈", 733, 53-56.

Plebanska, M. (2012). Podreczniki elektroniczne - przeglad dostepnych rozwiazan, IX ogolnopolska konferencje uczelni ekonomicznych "Rozwoj e-edukacji", 22 listop. 2012. Wroclaw: Fundacja Promocji i Akredytacji Ekonomicznych. 


\section{REFERENCES}

Bughajchuk, K. L. (2011). Elektronnyj pidruchnyk: ponjattja, struktura, vymoghy. Informacijni tekhnologhiji $i$ zasoby navchannja, Vyp. 22(2). Doi 10.33407/itlt.v22i2.437 (Electronic textbook: concept, structure, requirements)

Vydannja elektronni. Osnovni vydy ta vykhidni vidomosti. DSTU 7157:2010. (2010). (Electronic edition. Basic views and background information)

Vydannja. Osnovni vydy. Terminy ta vyznachennja. DSTU 3017:2015. (2015). (Edition. The main types. Terms and definitions)

Volynsjkyj, V. P. (2007). Teoretychni osnovy stvorennja elektronnykh pidruchnykiv. Problemy suchasnogho pidruchnyka: zbirnyk naukovykh pracj, 7, 28-30. (Theoretical foundations of creating electronic textbook)

Vorobecj, O. (2019). Informacijni tekhnologhiji u konteksti formuvannja cyfrovoji kompetentnosti majbutnikh uchyteliv. Elektronne naukove fakhove vydannja "Vidkryte osvitnje eseredovyshe suchasnogho universytetu". Specvypusk "Novi pedaghoghichni pidkhody v STEAM osviti", 398-404. Doi 10.28925/24140325.2019s36. (Information technologies in the context of forming the digital competence of future teachers)

Vorotnykova, I. (2019). Dosvid vykorystannja e-pidruchnykiv i elektronnykh zasobiv navchaljnogho pryznachennja $v$ umovakh cyfrovizaciji zaghaljnoji serednjoji osvity Ukrajiny. Informacijni tekhnologhiji i zasoby navchannja, 71(3), 23-39. Doi 10.33407/ itlt.v71i3.2552 (Experience of using etextbooks and electronic educational means in school within the framework of general secondary education digitalization in Ukraine)

Ilijchuk, L. (2019). Suchasni vymoghy shhodo rozrobky ta vprovadzhennja elektronnykh pidruchnykiv v osvitnij proces pochatkovoji shkoly. Elektronne naukove fakhove vydannja "Vidkryte osvitnje e-seredovyshhe suchasnogho universytetu". Specvypusk "Novi pedaghoghichni pidkhody v STEAM osviti", 123-132. Doi 10.28925/24140325.2019s11 (Current requirements for the development and implementation of electronic textbooks in the educational process of primary school)

Kononecj, N. V. (2009). Aspekty pedaghoghichnoji majsternosti vykladacha: rozrobka elektronnykh pidruchnykiv. Vytoky pedaghoghichnoji majsternosti: zbirnyk naukovykh pracj, 6, 202-210. (Aspects of pedagogical trade of teacher: development of electronic textbooks)

Kukharsjkyj, V., Oseredchuk, O. (2017). Elektronnyj pidruchnyk v ukrajinsjkij vyshhij osviti: vid ideji stvorennja do realizaciji. Visnyk Nacionaljnogho universytetu "Ljvivsjka politekhnika", 879, 84-90. (Electronic textbook in heis: from idea to implementation)

Madzighon, V. M. (2006). Teoretychni zasady stvorennja elektronnykh pidruchnykiv. Problemy suchasnogho pidruchnyka, 6, 34-38. (Theoretical foundations of creating electronic textbooks)

Pro zatverdzhennja Polozhennja pro elektronnyj pidruchnyk. (2018). № 440. (On Approval of the Regulation on the Electronic Textbook)

Pro zatverdzhennja Polozhennja pro elektronni osvitni resursy. (2012). № 1060. (On Approval of the Regulation on the Electronic Educational Resources)

Pro zatverdzhennja Porjadku zabezpechennja pidruchnykamy ta posibnykamy zdobuvachiv povnoji zaghaljnoji serednjoji osvity i pedaghoghichnykh pracivnykiv. (2019). № 41. (On Approval of the Procedure for provision of textbooks and manuals for the students of the complete general secondary education and teaching staff)
Pro provedennja eksperymentu vseukrajinsjkogho rivnja za temoju "Elektronnyj pidruchnyk dlja zaghaljnoji serednjoji osvity" (E-book for secondary education (EBSE)), serpenj 2018 roku - serpenj 2021 roku. (2018). № 957. (On conducting an allUkrainian experiment "An Electronic Textbook for General Secondary Education" (E-book for secondary education (EBSE)). August 2018 August 2021)

Rakov, S. A. (2005). Formuvannja matematychnykh kompetentnostej uchytelja matematyky na osnovi doslidnycjkogho pidkhodu v navchanni z vykorystannjam informacijnykh tekhnologhij. (Dys. doktora ped. nauk). Nacionaljnyj pedaghoghichnyj universytet imeni M. P. Draghomanova, Kharkiv. (Developing of the mathematical competencies of a mathematics teacher on the basic of research approach in education with ICT support)

Stakhiv, M. (2019). E-pidruchnyky dlja ukrajinsjkoji shkoly: problemy pidghotovky. Zapysky Ljvivsjkoji nacionaljnoji naukovoji biblioteky Ukrajiny imeni V. Stefanyka, 11 (27), 169-180. (E-textbooks for Ukrainian school: problems of preparing)

Figholj, N. (2012). Elektronnyj navchaljnyj posibnyk chy pidruchnyk: do problemy vyznachennja. Visnyk Nacionaljnogho universytetu "Ljvivsjka politekhnika": Serija "Problemy ukrajinsjkoji terminologhiji", 733, 53-56. (Electronic textbook ore textbook: the problem of definition)

Plebanska, M. (2012). Podreczniki elektroniczne - przeglad dostepnych rozwiazan, IX ogolnopolska konferencje uczelni ekonomicznych "Rozwoj e-edukacji", 22 listop. 2012. Wroclaw: Fundacja Promocji i Akredytacji Kierunkow Ekonomicznych.

Стаття надійшла 30.03.2020 p. 